\title{
University Autonomy, Academic Freedom and Academic Staff Union of Universities' (ASUU) Struggles in Nigeria: A Historical Perspective
}

\author{
A. K. Okorosaye-Orubite ${ }^{1}$, F. Godgift Paulley ${ }^{2} \&$ Nath. M. Abraham ${ }^{3}$ \\ ${ }^{1}$ Department of Educational Foundations, Faculty of Education, University of Port Harcourt, Choba, Nigeria \\ ${ }^{2}$ Department of Educational Foundations, Faculty of Education, Niger Delta University, Wilberforce Island, \\ Nigeria \\ ${ }^{3}$ Department of Educational Management, Faculty of Education, University of Port Harcourt, Choba, Nigeria \\ Correspondence: A. K. Okorosaye-Orubite, Department of Educational Foundations, Faculty of Education, \\ University of Port Harcourt, Choba, Rivers State, Nigeria. Tel: 234-803-341-0358. E-mail: \\ orubite2003@yahoo.co.uk
}

Received: March 29, 2012 Accepted: June 7, 2017 Online Published: September 27, 2012

doi:10.5539/ass.v8n12p265 URL: http://dx.doi.org/10.5539/ass.v8n12p265

\begin{abstract}
This paper takes a historical view of university autonomy and academic freedom in Nigeria from the 1960s to the present. It is the view of this paper that academic freedom and university autonomy have not fared well in Nigeria and this is one of the reasons the universities have not been contributing properly to national development.
\end{abstract}

Keywords: university, autonomy, academic, freedom, struggles, historical

\section{Introduction}

\subsection{The Origin of Universities}

Universitas, from where the concept of university is got, according to Fafunwa (2001:1) was first used to describe any group of people who were organized for some common purpose in a way resembling the later guilds during the medieval period in Europe. This period, it should be noted experienced great revival of learning in Europe being influenced by the "Arab scholars of Spain who studied the works of Aristotle, Euclid, Ptolemy, the new arithmetic and those texts of Roman law which had lain hidden through the Dark Ages" (Okafor, 1971:2). The guilds in the words of Boyd and King (1983:138) were simply societies of masters or students formed for the purpose of mutual help and protection from their masters.

There were in fact two types of universities during this period in Europe. According to Okafor (1971:3) there were the Universitas Scholarium in which the students banded together to employ their teachers, giving them appropriate conditions of service; and the other the Universitas Magistrorum in which the teachers banded together and selected their students, among other things. This was to protect the teachers from the chancellor, the bishop, the king or anyone else who tried to bring them under their control. It is the Universitas Magistrorum that has survived to this day.

Europe's two earliest universities were in Italy-Salermo in the South and Bologna in the North. Europe's third and fourth universities were in Paris and Oxford in France and England respectively. Oxford was developed in about 1167. Al-Azhar University in Cairo, Egypt is, however, the oldest university in the world, founded in 969 $\mathrm{AD}$.

It is from these beginnings that universities have been transported to all corners of the globe including Nigeria in 1948, when the University College, Ibadan was established.

\subsection{The Role of a University}

Fundamentally, the university exists to carry out the basic functions of teaching and imparting knowledge, to seek and discover truth through research, which for centuries have defined the genius of man; to disseminate its findings to all, so that mankind generally may shed the shackles of ignorance and want with the aim of making the world a better place to live in. In other words, the university according to Nzimiro (1975:53) as exemplified by the early ones were: 
entities consisting of persons passionately devoted to the search for the truth, wisdom and knowledge. Socrates brought home to mankind that the search for truth and its defence which the universities stand to protect cannot be compromised on the alter of material worldliness. He drank the hemlock poison offered him and died instead of recanting what he believed as the truth. To the rulers of his days, he was a heretic. To the youth he taught and to humanity till date, he towered above those that destroyed him.

The point being made here is that, the extent to which civilization can be sustained is dependent on the extent the intellectual momentum and vigor is being sustained by the universities.

With particular reference to the Nigerian society, the National Policy on Education (FRN, 2004:36) gave Nigerian universities the tasks of contributing to national development through high level relevant manpower training, development of intellect and inculcation of proper value orientation for the survival of the individual and society, developing the intellectual capacity of the individuals to understand and appreciate their environments, acquiring both physical and intellectual skills which would enable individuals develop to be self reliant and useful members of the community; promotion and encouragement of scholarship and community service; forging and cementing national unity; and to promote national and international understanding and interaction.

From the above, the university is more or less an industrial establishment for turning out most precious products-the accomplished individual. It is thus an agent for shaping not only the destiny of man but also of the state. It is a community of scholars, which believes in the superiority of the mind over matter and insists that everything material should be subordinated to the intellect. The university is, therefore, a place where concepts hallowed by age and tradition are subjected to severe scrutiny and knowledge grows through dissent, not through compromise. In order to enable the university carry out the above functions set out for it, it is required that the university should enjoy autonomy and academic freedom.

\subsection{What Then Is University Autonomy and Academic Freedom?}

University autonomy according to Ojo (1990:67) refers to the freedom granted each university to manage its internal affairs without undue interference from outside bodies, persons or most especially from the governments that in most parts of Africa sustain it financially. Ajayi cited by Ojo (1990:67) sees it in a similar way when he stated that it refers to "the right of institution, not the individual professional, to govern itself". This appears to be in line with the view of the Asbby Commission Report on Post School Certificate and Higher Education in Nigeria (FME, 1960:31) which recommends that:

A university has to be insulated from the hot and cold winds of politics. Responsibility for its management must be vested in an autonomous council. The council must include representatives of the public, but these representatives must attend as individuals and not as agents for some sectional interest or party line.

The Lima Declaration on Academic Freedom and Autonomy of Institutions of Higher Education, 1988 according to Fernando, Hartley, Nowak and Swinehart, (1990:187) state that institutional 'autonomy' means:

the independence of institutions of higher education from the state and all other forces of society, to make decisions regarding its internal government, finance, administration, and to establish its policies of education, research, extension work and other related activities.

In essence, it means free from the state and the interplay of politics in the internal affairs of the university administration. It is a necessary pre-condition for higher education institutions to fulfill their proper functions.

Academic Freedom on the other hand according to Nicol, a former Vice-Chancellor of Fourah Bay College, cited by Ojo (1990:49) is the "freedom of...professors and students... to be involved in creative processes leading to the discovery of new truths and confirmation of old ones." The Report of the UNESCO sponsored Conference on "the Development of Higher Education in Africa", Tananarive, 1962, sees academic freedom as "the freedom of academics to teach, to advance the frontiers of knowledge through research and to disseminate as widely as possible the results of their research" (UNESCO, 1963:12). Nocol quoted by Ojo (1990:49) states that:

Academic freedom cannot be regarded as implying exemption from the laws of the land as far as libel, slander, keeping of the peace and sedition are concerned. But a wise government will overlook the apparent transgressions of scholars if it is obvious that their intent is objectively critical and not maliciously subversive - a distinction sometimes difficult to recognize by dictatorships, one party states or military governments. 
The Lima Declaration comprehensively, defines 'academic freedom' as meaning "the freedom of members of the academic community, individually or collectively, in the pursuit, development and transmission of knowledge, through research, study, discussion, documentation, production, creation, teaching, lecturing and writing." It further defines an 'academic community' as covering "all persons teaching, studying, researching and working in an institution of higher education" (Fernando, Hartley Nowaka Swinehart: 1990:186-187).

The Lima Declaration is very important because before it, no instrument had addressed in a global context, the complex concepts of academic freedom and institutional autonomy. Accordingly, the ultimate aim of the Declaration is to promote internationally accepted standards of academic freedom and autonomy in higher institutions using that declaration as its basis to make measurement. Academic freedom, therefore, is a fundamental right of special importance to the proper functioning of the higher education sector. It is derived from the right to education and relates to the right to freedom of thought, opinion and expression.

Okafor (1971:155) in trying to establish a relationship between the two concepts states that when academic "freedom exists, autonomy automatically follows. But autonomy cannot exist without academic freedom in the modern sense" since the former allows for freedom to decide who, what, and how to teach or what research to undertake. Thus, according to Fernando et al (1990:9) autonomy is the institutional form of academic freedom and a necessary pre-condition to guarantee the proper fulfillment of the functions with which higher educational institutions are entrusted.

\section{The Relevance of Academic Freedom and University Autonomy in the Proper Functioning of the University}

The National Policy on Education (FRN 2004:37) considers the issues of academic freedom and autonomy as crucial for academic survival when it declares that "the internal organization and administration of each university will be left to the university." The document goes further to state the following areas as traditional areas of academic freedom for the universities:

(i) to select their students;

(ii) to appoint their staff;

(iii) to teach, select areas of research and disseminate the results of such researches; and

(iv) to determine the content of courses.

It should be noted that both concepts are seen as inheritance of modern universities from their medieval forefathers.

Harman (1983:504-506), McConnel (1981:36) and Okwor (2001:63) had all argued that university autonomy and academic freedom are indispensable for the proper functioning of the universities because of the following reasons, among others:

(i) that it is a traditional right which has worked well over the years.

(ii) that the responsibilities of creating new knowledge through scholarship and research, transmitting and preserving culture; developing the capacity in students for critical and independent judgment; and cultivating aesthetic sensitivities are carried out best in environment free from direct external control and domination.

(iii) that the complexity of academic work requires a fair measure of independence.

(iv) that autonomy provides for both staff and students checks and balances in a democratic society.

(v) that the intricacy and unpredictability of learning and investigation requires a high degree of freedom from external intervention and control if the university is to perform effectively; and

(vi) that it is necessary to ensure greater efficiency, economy and better morale among their staff and students.

Laprade (1953:105) in defence of academic freedom and university autonomy had advised his fellow university professors that:

the best hope of approaching truth, of arriving at an understanding of ourselves and of the world...rests in unfettered, honest, intelligent inquiry. This is our mission. If we do not prepare for it and keep ourselves free to perform it, we betray our trust.

In effect, therefore, academic freedom and university autonomy according to the Academic Staff Union of Universities, ASUU (1981:23-24) is necessary to safeguard "the highest standard of intellectual, social, moral 
and political performance of scholars." ASUU reasons that the universities will suffer from the following dangers in their inherent lack or deficiency of autonomy and academic freedom:

(i) inability of universities to pursue their sacred functions,

(ii) scholars being forced to owe loyalty to the party in power with the consequence of political consideration rather than concern for truth being the decisive factor in determining intellectual issues.

(iii) loss of job security

(iv) university councils, becoming rubber stamps for government decisions; and

(v) inevitable fall of standards.

\section{University Autonomy and Academic Freedom in Nigeria 1950 - 1970}

With the above stand and warnings as it were, one would have said that the standard of academic freedom and autonomy prevalent in many countries in Europe and America will be upheld in Nigeria. However, some incidents in the country's university system as shown below have completely belied this.

\subsection{The University of Ile-Ife Crisis of 1964}

The first sign that the inherited tradition of university autonomy and academic freedom were being eroded surfaced at the university of Ife (now Obafemi Awolowo University) in 1964, when the then Pro-Chancellor and acting Vice-Chancellor, Dr. S. D. Biobaku announced to a special congregation of the University on 19th December, 1963 that "the policy of the university is to support the government of the day, to which the University looked up for sustenance and that this is the credo of the University. The statement went on to add that "any member of staff who disagreed with the new policy should resign" (Ojo: 1990:51)

A week after the pro-Chancellor's speech, Professor Victor Oyenuga, Dean, faculty of Agriculture, was given seven days ultimatum within which to apologize or resign from the service of the university. His offence: for refusing to apologize to the Vice- chancellor for the contents of his letter of protest over a query he received because of his trip to Germany in June, 1963, without permission to read a paper on Nutrition in furtherance of knowledge, more so as the school was on holiday (Okafor 1971:138). Professor Oyenuga was accused of "bare faced disobedience" to the Vice-Chancellor and the council. He rejected the ultimatum and at its expiration; he was dismissed on February 3rd 1964.

The effect of this assault on the academic freedom of the professor in the university was that, Dr. Boye Fayemi, Dr. S.A Aluko. Dr. Olu Odumisu and Mr. Chambers resigned their appointments in protest that same day. Commenting on this, Fafunwa (1971:292) said "the University of Ife lost a number of competent staff from 1964 till 1966 and failed to recruit high caliber staff because of its 'credo' and anti- intellectualism as evidenced by the Council's unpopular action...". The statement credited to the Vice- Chancellor it should be noted went against the recommendations of the Ashby commission quoted above that "a university should be insulated from the hot and cold winds of politics" if it is to carry out the ideal functions assigned to it. The political undertone of the above incident is that, prior to this time, the Western Regional Government, the then proprietor of the university through its minister of Chieftaincy Affairs, Chief R.A Akinyemi according to Okafor (1971:136-37) had disclosed the intension of the regional government to close down the university. The reason for this action according to the minister was that, "the university was not keeping pace with her sister institutions in the country; blaming this on the inability of some lecturers to devote themselves to conscientious teaching but seeking only to propagate communism and to sabotage the efforts of the government." This statement was directed at the action Group as the Minister was a member of the national Council of Nigerian Citizens (NCNC) which was in coalition with the united people's party (UPP) in the regional cabinet.

\subsection{The Lindsay Episode at the University of Nigeria Nsukka- 1964}

Professor Lindsay, an Irishmen appointed to an Nsukka professorial position in1961 was terminated in 1964 due to a misunderstanding between him and the university authorities over his exercise of academic freedom through his publication University of Nigeria-Lindsay correspondence. In the said publication which he circulated to members of senate, Lindsay criticized the admission of students by the university to study Archeology (which was part of history department he headed) before the department was ready to offer it. Lindsay according to Okafor (1971:139-41) advanced two reasons why the programme should not start as at when the university proposed it. these were that: 
the university had been niggardly in distributing funds

there was a world shortage of competent archaeologists. In spite of these protests, the university still went ahead to admit students.

Apart from the above, he equally pointed out through his memorandum other areas of misguided decision on the part of the university administration which include

\section{bad planning}

setting up of a department of fisheries, some two hundred and fifty miles away from the sea. setting up of a school of Forestry and a school of Post- Graduate Librarianship, all to impress the outside world.

Lindsay in sum according to Okafor 91971:140) stated that “...the university has been grandiose and naïve in important areas of planning and less been indifferent to, or unaware of the cost in money and reputation for itself and of the consequence for the students".

The Vice-chancellor, Dr. G.M. Johnson reacted immediately by suspending Lindsay with power conferred on him by the University of Nigeria enabling law, accusing Lindsay of abuse of privilege of being a professor, member of staff in the History and Archeology Department, a member of senate as well as that of making erroneous statements and intemperate criticisms of the authorities of the University, including its Council.

Lindsay was warned after appearing before the Council of the University to defend his position, adding that should similar situation occurs in the future, Council would justifiably feel itself obliged to terminate his appointment. Describing the position of the Council, Nzirimo (1975:59-60) said the action was “...an attempt to create what is considered an administrative monster that almost annihilated the principles of academic freedom and intellectual excellence". Lindsay in spite of that warning was unrepentant as in a letter to Council, he claimed that the body was "astonishingly misinformed about the affairs of the university in his memorandum, adding that, all information in his memo was reasonably accurate since he consulted opinions outside his own field in making statement about Forestry, Fisheries and so on". this it should be noted is the essence of one being a university teacher - to propagate the truth among other things for the furtherance of the frontiers of knowledge.

On 31st August, 1964, Council terminated Lindsay's appointment as professor in the Department of history and Archeology as well as being a member of the academic staff of the University. Lindsay according to Okafor (1971:141) in his reaction did not take legal action against the university for the decision to terminate his appointment, but complained that "constructive criticisms given in course of his duty had been ruthlessly crushed". giving credence to the above assertion, Ojo (1990:64) had argued that academic freedom cannot take root in a society where... constructive criticisms are driven underground".

The Lindsay issue was a clear case of infringement on the freedom of an academic, as his comments though misconstrued by the university authority were premised on verifiable facts in the university as at that time.

\subsection{The Njoku Crisis at the University of Lagos - 1965.}

In October 1962, professor Eni Njoku, an Ibo by tribe, was appointed the first Vice-Chancellor of the University of Lagos. The appointment was for three years. On 1st of March 1965 it was reported by Nigeria's national newspapers that Dr. Sabiru Biobaku, then Pro. Chancellor of university of Ife had been appointed to succeed Njoku whose appointment would end on 31st may 1965. This according to Okafor (1971:141) came as a surprise for two reasons: firstly, Dr. Biobaku had only accepted the post of vice-Chancellor of the new University of Zambia, which he had not rejected and secondly Njoku had just not only been mentioned as Vice-Chancellor in the new bill that was proposed in 1964, but had actually been proposed by majority of the Senate of the University.

On the day of the announcement of Biobaku as Vice-Chancellor some students barricaded the gate of the University to protest against the appointment. The Senior Staff Association of the University equally supported the protest of the students through a resolution in the following proportion: 41 in support of the resolution condemning the change of the Vice-chancellor and 4 against the resolution and 6 abstaining. The protest of the senior staff took a different shape shortly as 45 staff dissociated themselves from the original resolution assuring Dr. Biobaku of their support and loyalty. Similarly, a split equally occurred in the students' body, some accused their counterparts who barricaded the University of being motivated by tribal sentiments engendered and actually supported by a political party. The matter became a politico- tribal issue, as the Younbas supported Biobaku and the Ibos gave their support to Njoku .

The Association of University Teachers of the University of Ibadan basking in the tradition of Oxford expressed 
their displeasure in the conflict over the appointment of a new Vice- Chancellor when the body asserted inter alia that:

\begin{abstract}
Standards by which competence for office are assured must be exclusively those of academic and administrative ability and personal character; political and tribal considerations should not enter... in order to maintain their high name and reputation before the nation and before the academic community of the world at large (Daily Times March 11:1965, cited in Okafor, 1971:142)
\end{abstract}

While the University of Ibadan teachers made this observation in defense of academic freedom and university autonomy, as it were, their counterparts at the University of Ife where Biobaku was the Pro-Chancellor announced full backing of Biobaku's appointment, not because Njoku was not academically fit, but because Biobaku was one of theirs- a Yoruba.

Expectedly, there was a unanimous argument at Nsukka, when the Association of University Teachers there condemned the injection of politics, remotely or otherwise into the working of universities in Nigeria. To counter this position a body which called itself "Organization for Nigerian University" according to Okafor (1971:143) asked the question, "...must both (that is university of Ibadan and Lagos as two federal government sponsored university in Nigeria) by all means be headed by members of one tribe?". This was because Dr. Dike an Ibo was head of Ibadan at the time.

Similar sentiments were being expressed in the Bayelsa State- owned Niger Delta University Wilberforce Island in 2007, over the appointment of professor Chris Ikporikpo as the substantive Vice-Chancellor, after the expiration of the tenure of the pioneer Vice-chancellor Professor J. C. Buseri. The grouse of most lecturers of Bayelsa origin and their administrative counterparts of the University over Ikporikpo's appointment was not that he was not qualified but because he is a non- indigene of Bayelsa State.

Though the events occurred in different universities and at different times, all of them have politics and tribalism as common factors uniting them. The point being made here, therefore, is that early in the life of university administration in the country, the fear expressed by the Ashby Report that "university should be insulated from the hot and cold winds of politics" became manifest.

\title{
4. Academic Freedom and University Autonomy during the Military Era: The Assaults and Academic Staff Union of Universities (ASUU) Responses
}

The Nigerian university system was more subjected to a lot of crises during the prolonged military rule (19661979 and 1984- 1999). the crises during this period manifested in the areas of gross under-funding, over crowdedness, understaffing, lack of infrastructure and physical despair of existing ones, violation of due process and above all suppression of academic freedom and university autonomy. Due to the above factors, the proper functioning of the universities in the country was hindered, thereby curtailing the positive contributions of the universities to national development.

Many academics who could not endure the heat of the hopeless situation in our universities left the shores of the country for greener pastures. However, those who remained according to Jega (2000:172) have never ceased in their struggle against the state misguided policies which had to a great extent threatened the essence of academic freedom and university autonomy through a better organized platform known as the Academic Staff Union of Universities (ASUU). ASUU according to Okeke (1997:131) was registered as a trade Union on 11th February 1978. on that platform, the academics have responded to military rule and their attendant repressive policies as they relate to the entire populace as the 'people's tribune' and to ensure university autonomy and academic freedom in particular.

Specifically, the military in Nigeria over the years had displayed the following to show their intolerance and contempt for academic freedom and university autonomy, to which ASUU had equally responded.

$\checkmark \quad$ Appointment of cronies as Vice- Chancellors in disregard for universities statues thereby establishing a reign of terror and repression on campuses. In one bizarre instance, an Army General was appointed Sole Administrator of Ahmadu Bello University, Zaria.

Appointments, promotions and discipline of staff being single- handedly done by such cronies Vice-Chancellors, with no regard to due process. Vice-Chancellors in order to appease their military benefactors more or less surrendered the autonomy of the universities.

$\checkmark \quad$ Harassment and outright dismissal of lecturers for exercising their rights to academic freedom. For example between 1977-79 when General Obasanjo was the Military Head of State, a Vice-Chancellor in the 
University of Calabar arbitrarily dismissed eighteen (18) lecturers (ASUU: 1981:3). After the 'Ali- Must- Go' riots of 1978, Students Union leaders were rusticated from their universities and barred from being admitted into any tertiary institution in Nigeria. At the same time their international passports were seized by the Federal Government so that they could not travel outside Nigeria for further education. When the ban on admission was lifted by the Alhaji Shehu Shagari's administration in 1981, the union leaders were further restricted from being readmitted into their former universities. Example of such leaders are Mr. Segun Okeowo, National President, National Union of Nigerian Students (NUNS) of the University of Lagos; and Mr. Ekpein Appah, Chairman, Care-taker Committee, University of Benin Student Union.

$\checkmark \quad$ The Obasanjo's military administration of 1976- 79 equally set up the Anya Commission on Academic Freedom and University Autonomy with the object of establishing a 'code of conduct' for staff and students which was to enable them function in ways supportive of the system, not to further the frontiers of knowledge and truth the pillars of the university community the world over. This move was successfully resisted by ASUU. Interestingly the committee was so scandalized by its terms of reference that it observed inter alia:

that the government... misunderstands the nature of the academic endeavour, the university system as a normative environment and what is more presumes that there is a prescriptive requirement for university to support all social positions. The greatest contribution of the Nigerian university is not blind support of all social situations, but its ability to save the nation from even temporary human error by always being positive to the human values which are not only universal but are necessary for our survival. (ASUU Undated:4).

$\checkmark \quad$ The Babangida era of 1985 -93 was one of the worst periods in the fight for academic freedom and university autonomy in Nigeria as the period was characterized by among other things, the culture of co-opting lecturers into government, harassment, intimidation and repression of those who refused to be co-opted using its appointed vice-Chancellors. They were tagged 'extremists' for opposing the policies of the government.

ASUU, the foremost union in the fight for academic freedom and university autonomy was repeatedly proscribed and its leaders sacked and/or detained. Dr. Festus lyayi, the then ASUU president was the first to fall victim of those considered 'extremists' as he was served with a letter summarily terminating his appointment with the university of Benin in May 1987 on the allegation that he had engaged in activities which violated university laws governing his employment. What was the activity- for being part of a seminar on an Alternative to structural adjustment Programme (SAP), the government anointed economic recovery policy.

$\checkmark \quad$ In Ahmadu Bello University (ABU), Zaria, the government at the same time arbitrarily terminated or voided the contract of expatriate staff because of their political views. In fact, Dr Patrick Wilmot was even deported because of his criticisms of government policies in furtherance of his academic freedom. He was deported on the ground that he was a spy of a foreign government. The story was the same in Calabar, Zaria, Benin, Ife, Nuskka and Maiduguri, among others. The victimized lecturers and students on political ground within this period according to Jega (1994:177) were close to five hundred.

There were threats of retrenchment of staff and increasing arbitrariness of university authorities in violation of statutes. For, instance, following the police massacre of ABU students in May 1986, the Panel according to Jega (1993:105) claimed that "some teachers who are members of ASUU in ABU (were) not teaching what they were paid to teach" and subsequently recommended that "those teachers should be flushed out by the authorities" This recommendation though a gross violation of academic freedom was accepted by the Government which directed the Federal Ministry of Education to take appropriate action. But for the reaction of ASUU to secure a court injunction, about twenty (20) lecturers were penciled down to be 'flushed out' (ASUU:1984). Such was the situation at the time of the military rule. Ihonvbere (1994:82) was therefore right when he declared that:

one cannot help but to conclude that the foundation of the university system in Nigeria has been destroyed by various military regimes aided by scores of 'intellectual rationalizes' who (served) as advisers, ministers... hangers- on, consultants and agents of the world bank. (these) academics.... collaborated in different capacities to erode strands of academic procedures, freedom and respect of the academic in the country. As a result, the institutions are no longer known for teaching and research, but for politics, manipulations, ethnic and religious jingoism, petty squabbles, political posturing, opportunism and the recycling of irrelevant theories, methodologies and ideas.

In spite of the above hopeless situation and threats to its members, ASUU has never ceased to take principled stands using the legal or constitutional means to resist the onslaught of the military on academic freedom and 
university autonomy until the military handed over power to the democratically elected government headed by chief Olusegun Obasanjo on the 29th of May 1999.

\section{The State of University Autonomy and Academic Freedom under the Civilian Administration of Chief Obasanjo: The Autonomy Bill and ASUU's Inputs}

With the coming on stream of a democratically elected government on 29th May 1999, it was expected that academic freedom and university autonomy will have a new lease of life. However, the facts on ground do not seem to realize that expectation. In 2001, there was a long drawn series of industrial actions embarked upon by ASUU before the Federal Government of Nigeria. (FGN) agreed to negotiate with ASUU on matters related to institutional funding, conditions of service, academic freedom and autonomy. After signing an agreement with ASUU, the FGN started dragging its feet on its implementation. It took a six-month long ASUU strike that made most universities in the country to lose one academic session before the FGN reluctantly implemented some major aspects of the agreement. In 2007 ASUU embarked on a three- month long strike to force the FGN to renegotiate the 2001 Agreement, which was due for renegotiation in 2004.

It is important to note that the industrial action lasted for three months because president Olusegun Obasanjo "was not worried, because I am not aware of why they are on strike.... they will burn out themselves because parents will send their children to private universities". This much Mr. President divulged on 25 May 2007 in a Nigerian Television Authority, NTA, network programme - The president Speaks. With a president that thinks this way what protection does one expect his administration to give academic freedom and university autonomy?

The government of chief Obasanjo, also pursued the issue of university autonomy and academic freedom constitutionally through the submission of a bill to the National Assembly known as the University Autonomy Bill in 2003. The was to mark 'new and better' provisions for the autonomy, management and administration of universities in Nigeria. ASUU's (Undated) careful analysis of the proposed bill reveals that, it is not only bad, but incurable, such that no part of it can be salvaged. The proposed bill was in fact worse than the Universities (Miscellaneous) Act of 1993 which it seeks to repeal, adding that the 1993 Act had certain essential elements to provide for autonomy and academic freedom.

In view of this, ASUU suggested that whatever additional provisions that may be needed to further protect university autonomy and academic freedom which constitute the soul of a university should be derived from the Agreements of 1983, 1992, 1999 and 2001 between the Federal Government and representatives of the University Community and be incorporated by way of amendments to the Act of 1993.

ASUU's position was premised on the following grounds (ASUU: Undated: 6-9):

\subsection{Its Provision Undermines University Autonomy and Vitiate the Essence of the University}

It vitiated the essence of the university by the way its objectives are defined and the prescribed organizational framework for the management of the university. It undermines university autonomy as it places in the hands of person/body of person external to the university the power to determine where to search for knowledge, what to transmit and disseminate as advanced knowledge, determine the course content and duration; thus making the universities extensions of the federal bureaucracy. Arbitrary and enormous powers which he never had before were given to the Visitor.

\subsection{Assault on the Principle and Practice of Democratic University Governance}

Contrary to all existing university laws, the Vice-Chancellor by the provision of the bill is made superior to the Senate of the university, as Senate under the proposed bill was to act merely in an advisory capacity to the Vice-Chancellor. The Vice-Chancellor by the provision can hire and fire subject to council's approval. This is entirely new in Nigeria and totally alien to the university tradition worldwide. Again, Vice-Chancellors are empowered to bye-pass Council and prepare and submit annual reports, and audited accounts of the university, direct to the Visitor through the National Universities Commission (NUC). The power of the Vice-Chancellor to appoint and dismiss Heads of Department, nominate persons to be appointed Registrar and Librarian as contained in the bill was undemocratic. Again, Heads of Department and elected representatives of Faculties or Congregation that are now members of Senate were not specifically provided for in the bill. The implication of this was that their inclusion was at the discretion of the particular Vice-Chancellor at any point in time, depending on the stand of the particular persons towards the affairs of the administration.

Council was to be dominated by external unelected members who owe their loyalty to the Visitor. Again in Council too, the Congregation which consists primarily of academics and alumni of the university is under-represented, as their seat in Council instead of being two as agreed between the Federal Government and ASUU was reduced to one. 


\subsection{Breaches of the Constitution}

The proposed bill breached the Constitution of the Federal Republic of Nigeria in the following ways among others.

The removal of the university service from the public service is a breach of the Constitution, for the university is specifically listed in the constitution as part of the public service. The abrupt and unilateral change of conditions of service of university academics in respect of age retirements, as well as their rights on retirement which are products of collective bargaining was a violation of established rights of academics protected by domestic laws and practices as well as international conventions to which Nigeria is a signatory. The provision of the bill preventing academics from withdrawing their services as a means of pressing for their industrial demands is a violation of international labour rights and conventions. Again, the bill's provision that the Federal Government can close down a university on the ground that its management does not conform to some NUC guidelines and not the law made by the National Assembly is another breach of the Constitution. That the Federal Minster of Education or the NUC is empowered to fill gaps in the bill when it comes into force is synonymous with the usurpation of the constitutional powers of the relevant law-making bodies both at the state and federal levels to legislate on the establishment of universities.

\subsection{Generation of Instability in the University System}

The proposed bill was capable of generating instability in the university system due to the dictatorial power of the Vice-Chancellor especially as it relates to the power to hire and fire, transfer of Senate power to discipline students to the Vice-Chancellor as well as the transfer of council's power to discipline staff to 'management'. Other areas include those introducing insecurity of tenure for academic staff and lack of specific tenure for the Vice-Chancellor are limits to academic freedom.

\subsection{Potential for Under-Developing Nigeria}

The bill in ASUU's thinking had the potential of under developing Nigeria due to the limits placed on academic freedom, as evidenced in the constraints in search of knowledge which might stimulate brain drain. Again, the reduced financial responsibilities of government to universities as well as the concentration of power of supervision of universities on the NUC will frustrate the efforts of the universities to contribute to national development.

\subsection{Putting Nigeria to Ridicule Internationally}

This is shown in the bill's section that provides for appointment and promotion of professors. This section reflects lack of understanding of the role of the university in the world today. This distorts and bastardizes the idea of the university internationally

5.7 Undermines the Social Welfare of Nigerian Academics and Students and Relieves Government of Its Responsibility to the Nigerian Citizens

Certain provisions of the bill place the responsibility of funding, research and other university activities on the shoulders of private organizations and individuals, instead of the government. By this arrangement, the welfare of both students and academics was not to be served, as such organizations and individuals will see their funding as an investment to generate profit.

\subsection{Violates FGN-ASUU Agreements}

Finally, the proposed bill violates certain sections of the various agreements reached between the FGN and ASUU through collective bargaining in 1983, 1992, 1999 and 2001. These sections include those on university autonomy (for example 1983 Agreement, Chapter Five of the 1992 Agreement and Chapter Six of the 2001 Agreement) and those on conditions of service as they relate to years of service and conditions for retirement (1992 and 1997).

In view of the above, ASUU prayed that the National Assembly should exercise its legislative power in defense of democracy and for the development of Nigeria by:

$$
\text { acknowledging the validity of the FGN- ASUU Agreement of 2001, and }
$$

consequently, relying on Chapter Six of that agreement which is on autonomy and academic freedom in enacting an amendment to the Universities (Miscellaneous) Act in the manner proposed in the draft bill prepared by the university academic community.

ASUU's prayer was accepted by the National Assembly as the bill that was sent to the president for his assent was the draft proposed by ASUU and not the Federal Executive Council's original Bill. Interestingly, the 
President assented to the bill on 10th Day of July 2003, before he got to know that what he signed was not the Federal Executive Council's Bill. As a result of this, 'The Universities (Miscellaneous provisions) Amendment Act', has not been put into operation.

\section{Conclusion}

We wish to conclude with the observations of Nzirimo (1975:74) thus:

Autonomy and freedom are only validated by a dogged display of maturity, sense of responsibility, vision and clear-sighted pursuit of goals and objectives that will, in short and long runs, provide salvation and progress for the people and the nation. The Universities (through their lecturers must) prove their worth. The nation (government) and people must learn to trust the universities; (for) our progress (as a state) depends on a working partnership between the people... the nation and the universities.

Interestingly, the teachers through ASUU have played their role creditably. The people are waiting to receive the dividends from the universities. This can only be possible if the state through the instrumentality of government will divorce politics from the administration of the universities in the country to make room for the needed progress through the granting of true academic freedom and autonomy to the universities.

\section{References}

Academic Staff Union of Universities (ASUU). (1981a). Memorandum presented to the presidential commission on the state of Nigerian universities and the conditions of service of university staff. Ibadan: National Secretariat.

ASUU. (1981b). Brief on the crisis in Nigerian universities. Ibadan: National Secretariat.

ASUU. (1984, July 5). The military administration and its tasks. Bulletin. Ibadan: National Secretariat.

ASUU. (2002). The Scholar. Ibadan: National Secretariat.

ASUU. (Undated). Comments on the bill for an act to provide for the repeal of the Universities (Miscellaneous) provisions act and to make new and better provisions for the autonomy, management and administration of universities in Nigeria and other matters connected to it. Ibadan: National Secretariat.

Boyd, W., \& King E. J. (1983). The history of western education. Akure: Fagbamigbe Publishers.

Fafunwa, A. B. (1971). A history of Nigerian higher education. Lagos: Macmillan and Company (Nigeria) Ltd.

Fafunwa, A. B. (2001). Crises and challenges on higher education: An overview. In A. U. Akubue, \& D. Enyi (Eds,). Crises and challenges in higher education in developing countries: A book of readings (pp. 1-15). Ibadan: Wisdom Publisher Ltd.

Federal Military Government. (1986). White paper on the Abisoye panel of inquiry into the killing of ABU students in May 1986. Lagos: Government Printers.

Federal Ministry of Education. (1960). Investment in education: Report of the commission on post-school certificate and higher education in Nigeria. Lagos: Government Printers.

Federal Republic of Nigeria. (2003). The universities (miscellaneous) amendment act. Abuja: Government Printers.

Federal Republic of Nigeria. (2004). National policy on education. Lagos: NERDC Press.

Fernado, L., Hartley, N., Nowak, M., \& Swinehart, T. (Eds.). (1990). Academic freedom 1990: A human report. London: Zed Books Ltd.

Harman, G. (1983). The erosion of university independence: Recent Australian experience. Journal of education, $12,501-518$.

Ihonvbere, J. (1994). Nigeria: The politics of adjustment and democracy. New Brunwick N.J: Transaction Publishers.

Jega, A. (1993). The professional associations and structural adjustment. In A. O. Olukoshi (Ed.), The politics of structural adjustment in Nigeria (pp. 97-111). Ibadan: Heinemann Educational Books Ltd.

Jega, A. (1994). Nigerian academics under military rule. Stockholm: University of Stockholm Press.

Jega, A. (2000). Nigeria universities and academic staff under military rule. In S. Federici, G. Caffentzis, \& O. Alidou (Eds.), A thousand flowers: Social struggles against structural adjustment in African universities. Eritrea: Africa World Press Inc. 
Laprade, W. T. (2003). Academic freedom and tenure. American association of university professors Bulletin, 38, 105-114.

Mc Connell, D. (1981). Autonomy and accountability, some fundamental issues. In P. Altbach, \& R. O. Berdahi (Eds.), Higher education in American society (pp. 30-49). Buffalo Prometheus Books.

Morrow, G. (1968). Academic freedom. Encyclopedia of social sciences, 1.

Nzimiro, I. (1975). University autonomy in Nigerian and other essays. Ibadan: The Caxton Press Ltd.

Ojo, J. D. (1990). Law and university administration in Nigeria. Lagos: Malthouse Press Ltd.

Okafor, N. (1971). The development of universities in Nigeria. London: Longman Group Ltd.

Okeke, B. S. (1997). Introduction to politics of education. Port Harcourt: Bengray Publishing Company.

Okwor, R. E. (2001). Constraints to university autonomy: The Nigerian perspective. In A. U. Akubue, \& D. Enyi (Eds.), Crises and challenges in higher education in developing countries: A book of readings (pp. 61-70). Ibadan: Wisdom Publishers Ltd.

United Nations Educational, Scientific, and Cultural Organization. (1963). The development of higher education in Africa: Report of the conference on the development of higher education in Africa. Paris: UNESCO. 